УДК 911.3:338.1:316.3(571.53)

АНАЛИЗ СТРУКТУРЫ ТУРИСТСКОГО ПОТОКА
В СЛЮДЯНСКИЙ РАЙОН ИРКУТСКОЙ ОБЛАСТИ

Бибаева А.Ю.

ФГБУН Институт географии им. В.Б. Сочавы СО РАН, Иркутск, е-mail: pav_a86@mail.ru

\begin{abstract}
Статья посвящена изучению внутригодовой структуры туристского потока в разрезе туристско-рекреационных зон Слюдянского района Иркутской области с целью разработки научно обоснованного подхода к территориальной организации туристско-рекреационной деятельности в Центральной экологической зоне Байкальской природной территории. Моделирование туристского потока производилось с учетом различных категорий рекреантов: организованный отдых в коллективных средствах размещения, самодеятельный палаточный отдых, маршрутный туризм, зимний спортивный отдых на горнолыжных курортах, экскурсионный и событийный туризм. Исходными материалами послужили официальные статистические данные, предоставленные администрацией Слюдянского района. В работе производилось восполнение недостающей информации посредством расчета по формулам, в том числе с использованием данных полевых исследований и социологических опросов. Отмечаются сложные моменты при учете различных категорий туристов. Так, в систему официального статистического учета не включены микропредприятия; большинство туристов, следующих по маршрутам в горы Хамар-Дабан, не регистрируются в главном управлении МЧС России. Согласно проведенной оценке объем турпотока в Слюдянский район в 2019 г. составляет 370-380 тыс. чел. В структуре туристского потока наибольшее число прибытий дают зимний спортивный туризм (34\%), центром которого является Утуликско-Байкальская туристско-рекреационная зона, организованный туризм $(29 \%)$ и экскурсионный туризм по Кругобайкальской железной дороге (23\%). Территории вне туристскорекреационных зон дают незначительную долю годового потока рекреантов - около $3,6 \%$ в год. В дальнейшем полученные данные о пространственно-временной структуре туристского потока послужат основой для расчета и регулирования рекреационных нагрузок на различные участки Центральной экологической зоны Байкальской природной территории.
\end{abstract}

Ключевые слова: Байкальская природная территория, моделирование, оценка, туристский поток, туристскорекреационная зона, Центральная экологическая зона

\title{
ANALYSIS OF TOURIST FLOW STRUCTURE TO THE SLYUDYANSKIY DISTRICT OF THE IRKUTSK REGION
}

Bibaeva A.Yu.

V.B. Sochava Institute of Geography SB RAS, Irkutsk, e-mail:pav_a86@mail.ru

\begin{abstract}
The article is devoted to the study of the intra-annual structure of the tourist flow of the context of tourist and recreational zones of the Slyudyanskiy district of the Irkutsk region. The research was carried out in the framework of the project to develop a scientifically-based approach to the territorial organization of tourist and recreational activities in the central zone of the Baikal natural territory. The modeling of the tourist flow was carried out taking into account various tourist's categories: organized recreation in collective accommodation facilities, camping on the coast of the Lake Baikal, route tourism, winter sports recreation at ski resorts, sightseeing and event tourism. The source materials are official statistics provided by the administration of the Slyudyanskiy district. In the study, the missing information was filled in by calculation using formulas and using data from field studies and opinion polls. There were difficult moments in accounting various categories of tourists. So, microenterprises are not included in the system of official statistical accounting; most of the tourists following the routes to the Khamar-Daban mountains are not registered at the main department of the Russian Emergencies Ministry. According to the assessment, the volume of tourist flow in the Slyudyanskiy district in 2019 is 370-380 thousand people. The largest volume of tourist flow are winter sports tourism (34\%) which is concentrated in the Utulik-Baikal tourist and recreation zone, organized tourism $(29 \%)$ and excursion tourism along the Circum-Baikal Railway $(23 \%)$. Territories outside the tourist and recreational areas account for a small proportion of the annual flow of recreants - about $3.6 \%$ per year. In the future, the obtained data on the space-time structure of the tourist flow will serve as the basis for calculating and regulating the recreational loads on various ecosystems of the Central ecological zone of the Baikal natural territory.
\end{abstract}

Keywords: Baikal natural territory, modeling, assessment, tourist flow, tourist and recreational zone, Central Ecological Zone

Ядром региональной туристской системы является озеро Байкал, которое формирует вокруг себя уникальное ландшафтно-географическое поле, требующее разработки научно обоснованного подхода к территориальной организации туристскорекреационной деятельности с учетом действующих природоохранных требований и направлений социально-экономического развития муниципальных районов. С этой целью Институтом географии им. В.Б. Со- чавы в 2017 г. были проведена научно-исследовательская работа «Расчет норм рекреационной нагрузки для организованного и неорганизованного отдыха в центральной экологической зоне Байкальской природной территории Иркутской области», в рамках которой осуществлено туристско-рекреационное зонирование муниципальных районов центральной экологической зоны Байкальской природной территории Иркутской области [1]. 
Настоящее исследование является продолжением начатых в 2017 г. работ [2, 3] по регулированию рекреационных нагрузок на природные экосистемы Байкальской природной территории.

Цель работы: оценка структуры туристского потока в туристско-рекреационные зоны Слюдянского района Иркутской области в 2018-2019 гг.

\section{Материалы и методы исследования}

В настоящее время информация, предоставляемая государственными органами статистики, а также материалы ежегодной отчетности органов власти, уполномоченных в области туризма, не позволяют получить требуемого массива данных для реализации целей исследования - а именно прогноза и регулирования рекреационных нагрузок на различные участки ЦЭЗ БПТ [1]. Возникает необходимость формирования собственной базы данных по каждой категории туристов.

С целью экспертной оценки туристского потока в Слюдянский район Иркутской области потоки посетителей были разбиты на следующие категории: организованный отдых в коллективных средствах размещения, самодеятельный палаточный отдых, маршрутный туризм, зимний спортивный отдых на горнолыжных курортах, экскурсионный туризм.

Основным источником информации о туристских потоках послужили статистические данные за 2018-2019 гг., предоставленные Администрацией Слюдянского района: количество КСР, численность размещенных лиц, число ночевок, коэффициент загрузки КСР, \%, количество неорганизованных туристов, событийный туризм, численность туристов на КБЖД, форма 1-КСР за 2019 г. Восполнение недостающей информации производилось по разработанной методике [4] расчета по формулам с учетом данных социологических исследований и полевых наблюдений. На основе исходных данных для каждой категории туристских потоков рассчитывались следующие показатели: количество единовременно пребывающих туристов, ежемесячный и годовой поток отдыхающих, объем туристического потока за определенный период (день, месяц, сезон, год) в человеко-днях по рекреационным местностям, муниципальным образованиям и туристско-рекреационным зонам.

Сложность учета потока организованных туристов заключается в том, что в систему официального статистического учета включены в основном крупные гостиничные комплексы, санатории и курорты, крупные базы отдыха, ранее имевшие статус ведомственных. Малые предприятия (микропредприятия, частные базы отдыха), превалирующие в границах ЦЭЗ БПТ, не подлежат обязательному учету и до недавнего времени в поле региональной статистики не включались [4].

В соответствии с формой 1 -КСР «Сведения о деятельности коллективного средства размещения» в 2019 г. по МО Слюдянский район число функционирующих коллективных средств размещения составило 32 единицы, из них 10 гостиниц, 10 других организаций гостиничного типа, 8 баз отдыха и других организаций отдыха (кроме турбаз), 2 туристические базы, 1 санаторий и 1 кемпинг. По периоду функционирования КСР подразделяются на круглогодичные 28 единиц и сезонные (летний период) 4 единицы.

Для полноты оценки туристского потока в Слюдянский район требуется учет деятельности микропредприятий, к которым в соответствии с п. 1 ч. 1.1 ст. 4 Ф3 «О развитии малого и среднего предпринимательства в Российской Федерации» № 209-Ф3 от 24.07.2007 г. [5] относятся субъекты предпринимательства, у которых за предшествующий календарный год среднесписочная численность работников не превышала 15 человек (пп «а» п. 2 ст. 4 Ф3 № 209), а доход не превысил 120 млн руб. [6]. Таким образом, недоучет потенциала номерного фонда микропредприятий приводит к недоучету части турпотока.

В реестре КСР Администрации Слюдянского района числится 37 коллективных средств размещения, ведущих деятельность в 2019 г., с общим потенциалом размещения 2688 койко-мест. Номерной фонд составил 955 единиц, из них 6 номеров высшей категории и 1 номер, приспособленный для проживания людей с ограниченными возможностями. По данным Администрации Слюдянского района в 2018 г. в КСР разместился 32971 человек.

По фондовым материалам Института географии им. В.Б. Сочавы СО РАН [7] число субъектов предпринимательства, оказывающих услуги по коллективному размещению физических лиц, с учетом микропредприятий, на 2017 г. составило 113 единиц, предоставляющих 5370 койко-мест сезонного размещения и 4288 койко-мест круглогодичного размещения, из них около $90 \%$ 
общего числа мест размещений сосредоточено в границах туристско-рекреационных зон (ТР3).

Основной проблемой учета туристов, следуюших по маршрутам, является их стихийный характер и невыполнение руководителями групп обязательств по регистрации маршрута в главном управлении МЧС России по Иркутской области. Особенно остро эта проблема стоит в Слюдянском районе, где наибольшей популярностью пользуются маршруты различных категорий сложности в горы Хамар-Дабана (пешие, велосипедные, сплавы по рекам). В последние годы заявки по учету туристских групп принимаются в электронном виде без посещения отделения МЧС.

Так, по данным подразделения ОГБУ «Пожарно-спасательная служба» Иркутской области в г. Слюдянка, за период с 29 мая 2019 г. по 1 февраля 2020 г. зарегистрировано 332 человека (из них $35 \%$ детей) в составе 38 туристских групп. На пик Черского через гидрометеостанцию (ГМС) проследовало 237 человек в составе 27 групп. Согласно журналу учета МЧС по маршрутам других направлений отправилось 95 человек в составе 11 групп. Они посетили следующие природные достопримечательные объекты: пер. Чертовы Ворота, пер. Поперечный, гора Босан, гора Золотая, голец Бабха, оз. Туристское, оз. Сердца, водопад Чарующий, р. Серебрянка, сплавы по рекам Иркут, Солзан, Утулик и др. Остальные группы автоматически выпали из статистического учета. По данным, предоставленным Администрацией Слюдянского района, годовой поток туристов, следующих по маршруту на пик Черского, составляет порядка 15 тыс. чел.

\section{Результаты исследования и их обсуждение}

Согласно проведенной экспертной оценке объем турпотока в Слюдянский район в 2019 г. составляет 370-380 тыс. чел. Наибольшее число прибытий дают три категории туристского потока: зимний спортивный туризм - 34\% (включая туристов, размещенных в КСР на территории БКГ «Гора Соболиная»»), организованный туризм - 29,7\% (около 110 тыс. чел.), экскурсионный туризм по Кругобайкальской железной дороге - $23 \%$ (рис. 1).

Структура туристского потока в Слюдянский район в разрезе туристско-рекреационных зон (ТР3) представлена в таблице.

Годовой турпоток в Култукско-Слюдянскую туристско-рекреационную зону в 2019 г. оценивается в 36 тыс. чел. Основной объем туристского потока дают организованный $(37 \%)$ и маршрутный туризм (42\%) (рис. 2). На территории зоны находятся 32 коллективных средства размещения, из них 6 расположены в п. Култук, 23 в г. Слюдянка и 3 - в п. Сухой ручей. Общий фонд мест размещения составляет 700 единиц - все круглогодичного использования. Поток организованных туристов оценивается в 13,5 тыс. чел. $\approx 12 \%$ от общего потока туристов данной категории в Слюдянский район.

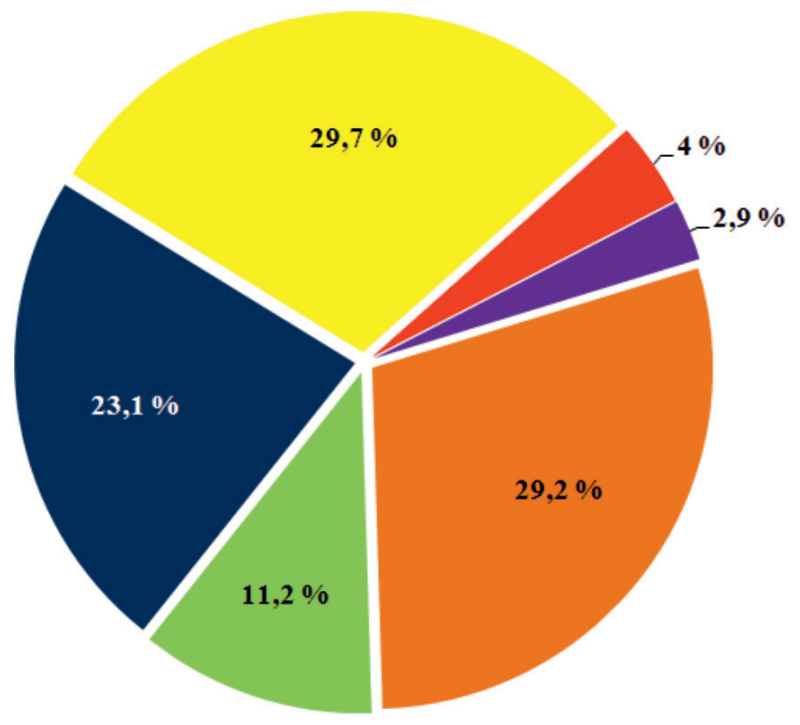

\section{Категории туристского потока:}

ш органнзованный

ш самодеятельный

- экскурсионный

зимний спортивный туризм

ш маршрутный

- событийный

Рис. 1. Структура турпотока в Слюдянский район в 2019 г. 
Структура турпотока в ТРЗ Слюдянского района по состоянию на 2018 г.

\begin{tabular}{|c|c|c|c|c|c|c|c|c|}
\hline \multirow[b]{2}{*}{ № } & \multirow[b]{2}{*}{$\begin{array}{c}\text { Туристско-рекреацион- } \\
\text { ная зона }\end{array}$} & \multicolumn{6}{|c|}{ Категория туристов } & \multirow[b]{2}{*}{ Всего } \\
\hline & & 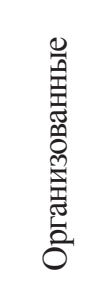 & 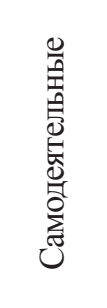 & 总 & 署署 & 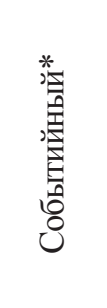 & 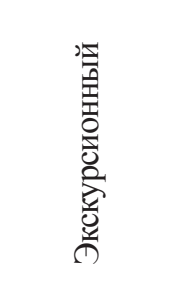 & \\
\hline 1 & Култукско-Слюдянская & 13502 & 3500 & 15000 & - & 4044 & нет данных & 36046 \\
\hline 2 & Утуликско-Байкальская & 71316 & 12321 & - & 111835 & 11529 & 87000 & 207001 \\
\hline 3 & Портбайкальская & 5763 & - & нет данных & - & - & нет данных & 92763 \\
\hline 4 & Муринская & 3890 & 4315 & нет данных & - & - & нет данных & 8205 \\
\hline 5 & Снежинская & 6979 & 19469 & нет данных & - & - & нет данных & 26448 \\
\hline 6 & Вне ТР3 & 10586 & 3138 & нет данных & - & - & нет данных & 13724 \\
\hline
\end{tabular}

П р и м е ч а н и е . * В соответствии с событийным календарем Слюдянского района [8].

Численность туристов, прошедших по маршруту на пик Черского, по данным Администрации Слюдянского района, составляет около 15 тыс. чел. Согласно записям журнала учета ОГБУ «Пожарноспасательная служба» Иркутской области в г. Слюдянка, за период с 29 мая 2019 г. по 1 февраля 2020 г. на пик Черского через гидрометеостанцию проследовало 237 человек в составе 27 групп, из них в холодный сезон (с 1 октября 2019 г. по 1 февраля 2020 г.) - 74 чел. в составе 9 групп, в теплый сезон (с 29 мая по 31 сентября 2019 г.) 163 чел. в составе 18 групп. В летний период в составе туристских групп преобладают дети $-56 \%$ (92 ребенка).

Поток самодеятельных туристов оценивается в 3,5 тыс. чел., что составляет около $8 \%$ от общего потока данной категории туристов в Слюдянский район.

Число прибытий в туристско-рекреационную зону, связанных с проведением различных мероприятий, составляет более 4 тыс. чел. Наиболее значимыми событиями в границах зоны являются «Лыжня Байкала», День города Слюдянки, День железнодорожника, «Скайраннинг - этап кубка России по бегу в гору». С 2005 г. в г. Слюдянка проводится празднование Дня Рождения Байкальского Деда Мороза, которое посещают около 3000 чел. В рамках фестиваля проводятся лыжные гонки, конкурсы детских творческих работ. В последние несколько лет становятся популярными «Именины Ероши» (бурундучка - символа г. Слюдянка) и тропы на пик Черского.
В рамках экспедиции в Слюдянский район в феврале 2020 г. было проведено исследование числа рекреантов, отдыхающих (без ночевки) в зимний период на побережье Байкала в районе мыса Шаманский в г. Слюдянка. Подсчет туристов проводился в будние и выходные дни. Единовременное число отдыхающих в среднем составило 65 человек в будние дни и 128 человек - в выходные дни. Принимая во внимание период устойчивого безопасного ледового покрова оз. Байкал (февраль - март), кратность заездов в день равным 2, число выходных дней за указанный период - 19, будних дней - 40, поток отдыхающих в прибрежной зоне в зимний период составляет не менее 10 тыс. чел.

Турпоток в Утуликско-Байкальскую туристско-рекреационную зону обеспечивает около $54 \%$ всех прибытий Слюдянского района, что составляет более 207 тыс. туристов в год (таблица). В настоящее время по имеющемуся фонду мест размещения Утуликско-Байкальская ТРЗ занимает лидирующие позиции в Слюдянском районе 3,4 тыс. койко-мест, что составляет $31,5 \%$ от общего потенциала размещения. Из них около $82 \%$ мест используется круглогодично. По данным экспертной оценки, в 2019 г. здесь разместилось более 71 тыс. чел.

Поток самодеятельных туристов, размещающихся в палатках, составляет 12,3 тыс. чел. и приурочен к прибрежным зонам оз. Байкал в п. Утулик (в районе турбаз «Байкал», «Солнечный берег Байкала», от устья p. Утулик до ул. Российская), п. Солзан (в устье р. Солзан), в районе устья р. Бабха. 


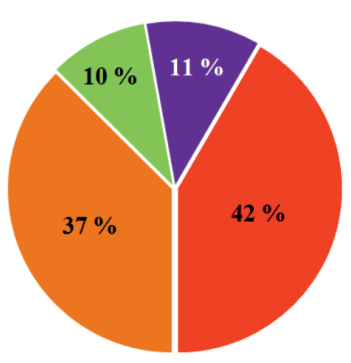

Култукско-Слюдянская

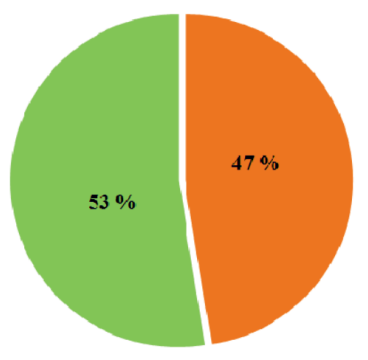

Муринская

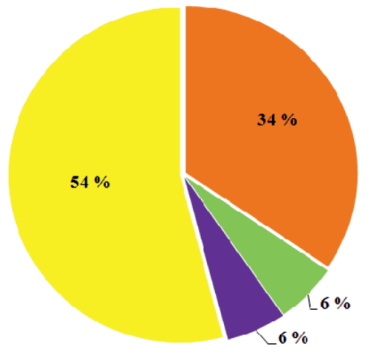

Утуликско-Байкальская

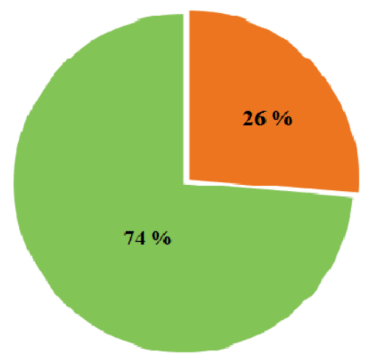

Снежинская

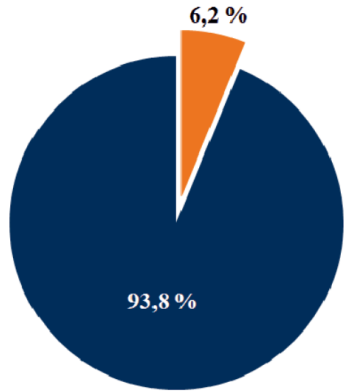

Портбайкальская

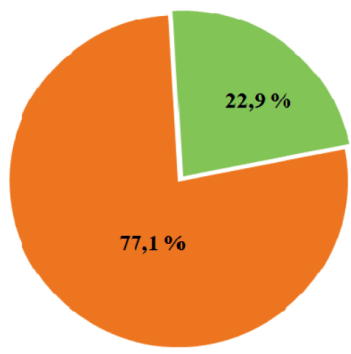

Bне TP'

Категории туристского потока:

\begin{tabular}{|c|c|c|}
\hline Ш организованный & — событийный & ш экскурсионный \\
\hline самодеятельный & п маршрутный & зимний спортивный \\
\hline
\end{tabular}

Рис. 2. Структура турпотока в туристско-рекреаџионных зонах Слюдянского района в 20192.

Маршрутный туризм развивается вдоль рек Утулик, Бабха и Солзан. Оценка турпотока по маршрутам требует дополнительных полевых исследований.

Мощнейшим стимулом для посещения территории является событийный туризм, который является дополнительным источником привлечения более 11,5 тыс. туристов в течение всего года и в межсезонье. Они составляют около $71 \%$ потока данной категории туристов Слюдянского района; из них около 11 тыс. чел. приходится на г. Байкальск (таблица, рис. 2).

Центром притяжения зимнего спортивного и событийного туризма является БГК «Гора Соболиная». С целью популяризации горнолыжного спорта, привлечения к активному и здоровому образу жизни БГК «Гора Соболиная» организует ряд зимних мероприятий - «Рождественские старты», «Кубок Горы Соболиной» (1-й, 2-й этапы, «Соболёк»), «Сибирячок», «Королева горы», посвященный Международному женскому дню, «День защитника Отечества», «Спуск в купальниках», Кубок
«Сервико», Кубок «КрайсНефти», в рамках которых проходят соревнования по зимним видам спорта среди детей, мужчин и женщин. Летний туристический сезон связан с такими мероприятиями, как фестиваль «Территория лета», Конкурс «GrillFest», фестиваль скандинавской ходьбы «Байкальский нордик» и др. Согласно данным Администрации Слюдянского района мероприятия, организуемые БГК «Гора Соболиная», в 2019 г. посетило не менее 7,5-8 тыс. чел., при этом в 2019 г. годовой поток туристов сюда составил 126,7 тыс. чел., из них около 110 тыс. чел., занимающихся зимним спортивным туризмом.

Визитной карточкой Слюдянского района и г. Байкальска в частности является Клубничный фестиваль «Виктория». Он проходит в середине июля, в рамках фестиваля проводится культурно-развлекательная программа, организуются рынки, где можно приобрести свежую ягоду и различные лакомства из клубники. По оценкам Администрации Слюдянского района фестиваль посещают около 1,5 тыс. чел. 
Объем турпотока в Портбайкальскую туристско-рекреационную зону в 2019 г. оценивается в 92,7 тыс. чел. (таблица). Территория является труднодоступной с точки зрения транспортной инфраструктуры. Основной категорией туристов здесь являются экскурсионные группы, путешествующие по Кругобайкальской железной дороге (КБЖД). Архитектурно-ландшафтный комплекс КБЖД является памятником архитектуры и инженерного искусства мирового уровня, национальным достоянием России, имеющим исключительную эстетическую ценность. С полотна железной дороги открываются живописнейшие панорамные пейзажи дальней перспективы, гармонично сочетающие таежные «моря», остепненные склоны со скальными останцами, круто обрывающиеся в бескрайние воды Байкала скальные уступы и сотни рукотворных уникальных нетиповых сооружений - тоннелей, каменных галерей, мостов и виадуков, подпорных стенок, подчеркивающих и преумножающих эстетические достоинства уникальных природных ландшафтов.

Однодневные туры по Кругобайкальской железной дороге совершают три вида железнодорожных составов.

1. Кругобайкальский экспресс. В качестве локомотива используется тепловоз с двигателем внутреннего сгорания, работающим на дизельном топливе (РА-1, РА-2). Это современный состав с 8-10 комфортабельными вагонами на 50-60 посадочных мест, курсирует в теплый период года с мая до середины ноября, осуществляет 6 рейсов в неделю.

2. Ретропоезд. В качестве локомотива используется паровоз с паросиловой установкой, работающей на угле. Состав ретропоезда включает 8-10 комфортабельных вагонов на 50-60 посадочных мест, курсирует в теплый период года - с мая до середины ноября, осуществляет 6 рейсов в неделю.

3. Рельсовый автобус - тепловоз модели PA-1, РА-2 (на дизельной тяге) с 8-10 утепленными вагонами на 50-60 посадочных мест, курсирует в зимний период года с декабря по апрель, осуществляет 4 рейса в неделю или менее в зависимости от наполняемости вагонов.

По сравнению с 2017 г. в 2019 г. увеличилось число вагонов в составе поезда до 10 единиц и, соответственно, увеличилось максимальное единовременное число пассажиров для перевозки - до 500-600 чел., что обусловлено растущим спросом на экскурсионные туры данного направления [9]. Обследование, проведенное в августе 2017 г., показало уровень загрузки вагонов поезда $70 \%$. Для расчета потока туристов в зимний период доля загрузки вагонов поезда принята за $40 \%$. Таким образом, число туристов, посетивших КБЖД в 2018 и 2019 гг., может составлять от 72 тыс. до 87 тыс. чел. в год, или около 9,5-11,5 тыс. чел. ежемесячно в теплый период года и 1,7-2,1 тыс. чел. ежемесячно в холодный период года.

В границы ТРЗ входит единственный населенный пункт - п. Байкал, в котором расположено 7 коллективных средств размещения. Доля мест для круглогодичного использования в общей численности мест размещения туристов и отдыхающих составляет $100 \%$ (160 койко-мест). Поток организованных туристов в туристскорекреационную зону составляет 5,7 тыс. чел. - около $5 \%$ от потока организованных туристов в Слюдянский район.

Самодеятельный туризм не развит в силу практического отсутствия пляжных полос, вдоль побережья преобладают скалистые обрывы. Оценка потока туристов по маршрутам вдоль железной дороги требует полевых исследований. Мероприятий, проводимых в данной ТР3, в событийном календаре [8] Слюдянского района не числится.

Общий объем турпотока в Муринскую туристско-рекреациионнюю зону в 2019 г. оценивается в 8,2 тыс. чел. (таблица), что составляет около $2 \%$ годового туристского потока Слюдянского района. Структура годового турпотока в Муринскую туристско-рекреационную зону представлена на рис. 2. Вклад в туристский поток исследуемой зоны вносят две категории рекреантов - организованные и самодеятельные. В соответствии с реестром КСР услуги по размещению туристов оказывают 2 объекта в п. Мурино - база отдыха «Энергетик» на 156 мест круглогодичного использования и база отдыха «Мурино», предоставляющая 25 мест в гостевых домиках (сезонность не определена). Согласно полученным данным, в 2019 г. число посетителей, разместившихся в КСР Муринской туристско-рекреационной зоны, составило 3,9 тыс. чел. (47\%); доля в годовом турпотоке организованных туристов Слюдянского района составляет $3,5 \%$.

Места самодеятельного отдыха локализованы в районе п. Мурино на побережье о3. Байкал. Годовой поток данной категории 
отдыхающих соизмерим с потоком организованных туристов и составляет 4,3 тыс. чел. $-53 \%$; доля в годовом турпотоке самодеятельных туристов Слюдянского района составляет $10 \%$.

Данные о прохождении туристов по маршрутам в данной туристско-рекреационной зоне немногочисленны. За период с 29 мая 2019 г. по 1 февраля 2020 г. имеется одна запись в журнале учета отделения МЧС в г. Слюдянка - пеший маршрут группой из 5 взрослых человек на 7 дней на Осиновский голец с выходом к р. Хара-Мурин.

Годовой объем турпотока Снежинской туристско-рекреационной зонь составляет 26,5 тыс. чел. В границах ТР3 находятся 3 коллективных средства размещения: База отдыха «Гостевые домики» на 33 койко-места, которая в 2019 г. не функционировала ввиду устранения нарушений; рекреационный комплекс « $\mathrm{S}^{*}$ нежная», обеспечивающий 122 койко-места в теплый сезон, из которых 63 используются круглогодично; гостиница «Теплые озера на Снежной», предоставляющая для размещения 200 койко-мест круглогодично. Общий фонд койко-мест в 2019 г. составляет 322 единицы сезонного использования и 263 единицы круглогодичного использования. Численность организованных туристов в 2019 г., согласно экспертной оценке, составила около 7 тыс. чел., что составляет $6 \%$ от годового потока организованных туристов в Слюдянском районе.

Для данной туристско-рекреационной зоны характерно преобладание самодеятельного вида туристской деятельности над организованным в 2,8 раза. Поток самодеятельных туристов оценивается в 19,5 тыс. чел., что обеспечивает почти половину - 46 \% (!) годового потока самодеятельных туристов Слюдянского района. Наиболее популярные места палаточного отдыха сосредоточены на побережье оз. Байкал в районе п. Паньковка 2-я (0,7 тыс. чел.) и п. Новоснежная (16,9 тыс. чел.) и на побережье р. Снежная - Теплые озера (1,8 тыс. чел.). При этом основная рекреационная нагрузка приходится на прибрежную зону п. Новоснежная, где единовременное число отдыхающих составляет 900-1000 чел.

За пределами туристско-рекреационных зон находятся 18 коллективных средств размещения общим фондом койко-мест 551 сезонного и 392 круглогодичного использования, расположенных в п. Буровщина. п. Мангутай, п. Солзан, п. Муравей, вдоль
КБЖД - п. Половинная, п. Шарыжалгай, п. Ангасолка. Общий объем организованного потока туристов составляет 10,5 тыс. чел. в год, что составляет около 9,5\% от общего потока организованных туристов Слюдянского района.

Поток самодеятельных туристов составляет 3,1 тыс. чел. и направлен главным образом на побережье Байкала в районе п. Буровщина, п. Паньковка 1-я, п. Мангутай, п. Муравей. Ввиду широкого распространения берегов с крутыми и отвесными склонами и фрагментарным развитием аккумулятивных форм рельефа береговой зоны вдоль полотна КБЖД поток самодеятельных туристов, ночующих в палатках на побережье, здесь незначителен. Вклад самодеятельных туристов в годовой поток данной категории отдыхающих Слюдянского района составляет около $7 \%$.

Для территорий, не вошедших в ТР3, характерно преобладание организованного потока туристов над самодеятельным в 3,4 раза (!).

Данные по маршрутному туризму немногочисленны. В журнале учета отделения МЧС в г. Слюдянка в период с 29 мая 2019 г. по 01 февраля 2020 г. зарегистрирована одна группа из четырех человек, прошедших в течение четырех дней в сентябре по маршруту вдоль р. Солзан на водопад Чарующий.

Таким образом, годовой турпоток вне туристско-рекреационных зон Слюдянского района составляет 13,7 тыс. чел. - 3,6\% от годового турпотока Слюдянского района (таблица, рис. 2).

\section{Заключение}

В соответствии с экспертной оценкой, основной туристский поток Слюдянского района направлен в Утуликско-Байкальскую туристско-рекреационную зону, являющуюся центром зимнего спортивного туризма, и Портбайкальскую туристско-рекреационную зону, лидирующую по потоку экскурсантов (рис. 3). Наименьший вклад в объем турпотока в Слюдянский район вносит Муринская туристско-рекреационная зона (2,1\%). Территории вне туристскорекреационных зон дают незначительную долю годового потока рекреантов - около $3,6 \%$ в год.

Основными категориями туристов в Слюдянском районе, обеспечивающими примерно равное количество посетителей, являются организованные, зимнего спортивного отдыха и экскурсионные. 


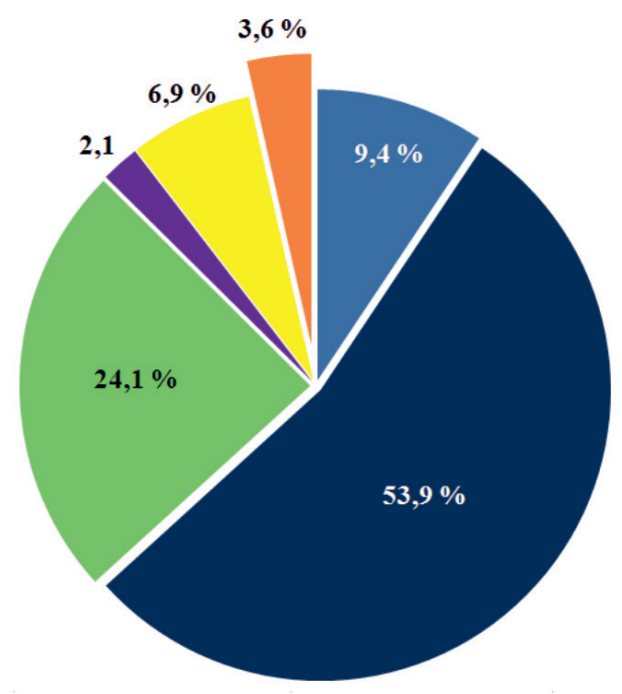

Туристско-рекреационные зоны:

шултукско-Слюдянская

- Утуликско-Байкальская

портбайкальская

- Муринская

Снежинская

вне ТP3

Рис. 3. Распределение годового турпотока по туристско-рекреационным зонам Слюдянского района в 2019 г.

Данные об объеме и структуре турпотока в Слюдянский район являются основой для организации мониторинга рекреационных воздействий на ландшафты и контроля состояния и охраны природно-рекреационного потенциала территории. Для оценки туристских потоков в полном объеме органам местного самоуправления рекомендуется, тщательно вести реестры КСР по всем показателям; проводить учет экскурсантов, самодеятельных туристов, отдыхающих на пляжах и идущих по маршрутам (пеших, по воде и др.) посредством социологических исследований путем опроса или анкетирования. Это позволит им владеть информацией, иметь доказательную базу при решении вопросов, связанных с оценкой рекреационных нагрузок, и инструмент регулирования и планирования рекреационной деятельности.

Исследование выполнено за счет средств государственного задания ААAAА17-117041910167-0 и при финансовой поддержке РФФИ в рамках научного проекта № 20-45-380012 p_a.

\section{Список литературы / References}

1. Евстропьева О.В., Бардаш А.В., Будаева Д.Г. Методологические подходы к туристско-рекреационной дифференциации территорий с особыми условиями использования // Современные проблемы сервиса и туризма. 2019. Т.13. № 1. C. 7-21. DOI: 10.24411/1995-0411-2019-10102.

Evstropeva O.V., Bardash A.V., Budaeva D.G. Methodological approaches to the tourism and recreational differentiation of territories with special use conditions // Sovremennye problemy servisa i turizma. 2019. V.13. № 1. P. 7-21 (in Russian).

2. Корытный Л.М., Евстропьева О.В. О разработке правил организации туризма и отдыха в центральной эко- логической зоне Байкальской природной территории // Современные проблемы сервиса и туризма. 2018. Т.12. № 3. C. 31-42. DOI: 10.24411/1995-0411-2018-10303.

Korytny L.M., Evstropeva O.V. On the developing the rules for organization of tourism and recreation in the central ecological zone of the Baikal natural territory // Sovremennye problemy servisa i turizma. 2018. V. 12. № 3. P. 31-42 (in Russian).

3. Заборцева Т.И., Евстропьева О.В., Дуля К.В. Потенциал развития туристско-рекреационной деятельности на территории ЦЭЗ БПТ (по результатам пилотного анкетирования)// Современные проблемы сервиса и туризма. 2019. T. 13. № 1. C. 60-69. DOI: 10.24411/1995-0411-2019-10107.

Zabortseva T.I., Evstropeva O.V., Dulya K.V. Development potential of tourist and recreational activities in the territory of the Central ecological zone of the Baikal Natural Territory (pilot survey-based evaluation) // Sovremennye problemy servisa i turizma. 2019. V. 13. № 1. P. 60-69 (in Russian).

4. Евстропьева О.В., Бибаева А.Ю., Санжеев Э.Д. Моделирование туристских потоков на региональном и локальном уровнях. Опыт реализации в ЦЭЗ БПТ // Современные проблемы сервиса и туризма. 2019. Т.13. № 1. С. 85-97. DOI: 10.24411/1995-0411-2019-10110

Evstropeva O.V., Bibaeva A.Yu., Sanzheev E.D. Modeling tourist flows at the regional and local levels. Experience of implementation in the Central ecological zone of Baikal natural territory // Sovremennye problemy servisa i turizma. 2019. V. 13. № 1. P. 85-97 (in Russian).

5. О развитии малого и среднего предпринимательства в Российской Федерации: Федеральный закон № 209-Ф3 от 24.07.2007 г. (с изменениями от 27.12.2019 и доп., вступ. в силу с 01.01.2020). Консультант Плюс. [Электронный pecypc]. URL: http://www.consultant.ru/document/cons doc LAW_52144 (дата обращения: 25.05.2020).

On the development of small and medium-sized enterprises in the Russian Federation: Federal Law № 209-FL of July 24, 2007 (changed 27.12.2019 and 01.01.2020). Konsul'tant Plyus. [Electronic resource]. URL: http://www.consultant.ru/ document/cons doc LAW 52144 (date of access: 25.05.2020) (in Russian).

6. О предельных значениях дохода, полученного от осуществления предпринимательской деятельности, для каждой категории субъектов малого и среднего предпринимательства: Постановление Правительства Российской Федерации № 265 от 4 апреля 2016 г. Консультант Плюс. [Электронный ресурc]. URL: http://www.consultant.ru/document/ cons doc LAW 196415/ (дата обращения: 25.05.2020). 
On the limit values of income derived from entrepreneurial activity for each category of small and medium-sized enterprises: Decree of the Government of the Russian Federation № 265 of April 4, 2016. Konsul'tant Plyus. [Electronic resource]. URL: http://www.consultant.ru/document/cons_doc_LAW_196415/ (date of access: 25.05.2020) (in Russian).

7. Расчет норм рекреационной нагрузки для организованного и неорганизованного отдыха в центральной экологической зоне Байкальской природной территории Иркутской области. Отчет о научно-исследовательской работе. Иркутск: Институт географии им. В.Б. Сочавы СО РАН 2017. $428 \mathrm{c}$.

Calculation of the norms of recreational load for organized and unorganized recreation in the central ecological zone of the Baikal natural territory of the Irkutsk region. Research Report. Irkutsk: Institut geografii im. V.B.Sochavy SO RAN, 2017. 428 p. (in Russian).
8. Событийный календарь южного Прибайкалья (Слюдянский район). [Электронный ресурc]. URL: http:// www.sludyanka.ru/cobytijnyj-kalendar (дата обращения: 05.06.2020).

Event calendar of the southern Baikal region (Slyudyanskiy district). [Electronic resource]. URL: http://www.sludyanka.ru/ cobytijnyj-kalendar (date of access: 05.06.2020) (in Russian).

9. ВСЖД: Движение туристических поездов по КБЖД планируем сделать круглогодичным. Сибирское информационное агентство, 2019. [Электронный ресурc]. URL: https:// sia.ru/?section=484\&action=show_news\&id=385385 (дата обращения: 25.05.2020).

ESR: it is planned to make the movement of tourist trains on the Circum-Baikal Railway year-round. Sibirskoe informacionnoe agentstvo, 2019. [Electronic resource]. URL: https://sia. $\mathrm{ru} /$ ?section $=484 \&$ action $=$ show news \&id $=385385$ (date of access: 25.05.2020) (in Russian). 